\title{
OROPHARYNGEAL SQUAMOUS CELL CARCINOMA TREATED CONCURRENTLY WITH CETUXIMAB: A CASE REPORT OF INTOLERANCE TO CISPLATIN IN YOUNG AGE
}

\author{
Aista Plieskienė, Alvydas Česas \\ Klaipéda University Hospital, Klaipèda, Lithuania
}

Keywords: concurrent chemoradiotherapy, cisplatin, cetuximab; human papilloma virus; base of tongue; oropharyngeal carcinoma.

\begin{abstract}
Summary
Squamous cell carcinoma of the oropharynx is a common case of head and neck cancer related to human papillomavirus. We present a case of moderately (G2) differentiated squamous cell carcinoma, which responded well to concurrent radiotherapy with cetuximab after intolerance of cisplatin. A 37-year-old woman referred to our hospital for a locally advanced cancer of the base of tongue. Physical examination revealed an ulcerative tumor with spread to the supraglottic structures, and swelling of the right side cervical lymph node at group IIA. The histological diagnosis from a biopsy specimen was moderately differentiated $\mathrm{p} 16$ positive squamous cell carcinoma. The patient underwent cisplatin-based concurrent chemoradiotherapy. Two - three weeks after receiving an intravenous cisplatin dose $100 \mathrm{mg} / \mathrm{m}^{2}$ for the first day of chemorradiation, the patient presented with profound bilateral sensorineural hearing loss. The cisplatin-based chemotherapy had changed to alternative agent. The patient continuously underwent concurrently radiation with cetuximab without the break of radical radiotherapy course. The patient experienced partial recovery of hearing after radical treatment of cancer. Complete clinical and radiological response of oropharyngeal squamous carcinoma was achieved.

Conclusions. Toxicity with only one standard dose of cisplatin can be profound also in young age. This risk should be addressed when counseling patient prior to initiation of treatment. In case of platinum ineligibility, replacing cisplatin with less toxic agent cetuximab may be taken into consideration for $\mathrm{p} 16$ positive carcinoma of the oropharynx.
\end{abstract}

\section{Introduction}

The epidemiology of head and neck squamous cell carcinoma (HNSCC) has shifted dramatically over the last 50 years, as smoking-related HNSCCs decrease in incidence while human papillomavirus (HPV)-related cancers rise. Head and neck squamous cell carcinomas related to HPV are generally more sensitive to chemotherapy and have better prognoses $[1,2,3]$. The meta - analysis of chemotherapy in head and neck cancer demonstrated a $6.5 \%$ absolute improvement in 5 -year overall survival with concurrent chemo-radiotherapy (CCRT) over radiotherapy (RT) alone. Concurrent highdose cisplatin (100 mg/m2 on days 1, 22 and 43 during RT) was identified as the most effective regimen [4]. Definitive concurrent chemoradiation with high-dose cisplatin is therefore regarded as the preferred choice in the European and NCCN clinical practice guidelines for the treatment of fit patients with loco-regionally advanced squamous cell head and neck cancer [5].

Cetuximab, a molecular agent targeted against epidermal growth factor receptor, is reported to have significant efficiency in treatment of head and neck squamous cell carcinoma [6]. The use of cetuximab as an alternative to high-dose cisplatin, the recommendations in Europe differ from those formulated in the NCCN guidelines [5,7]. There has been no randomized phase III trial reported that compares cetuximab/RT with cisplatin-based concurrent chemorradiation (CCRT) [7].

We present here a case of locally advanced $\mathrm{p} 16$ positive carcinoma of the base of tongue r/cT3N1M0 that completely responded after concurrent chemorradiation after first cycle of cisplatin has changed effectively due to sensorineural hearing loss to concurrent radiation with cetuximab.

\section{Case report}

A 37-year-old woman was referred to our hospital in April 2019, because of a tumor on the right-side of her base 
of tongue. She had no history of smoking or alcohol-related problems. Her nutrition was normal. Physical examination showed an ulceration of overlying mucosa and hard tumorous lesion on the right side of the base of the tongue, with a size of approximately $25 \times 20 \mathrm{~mm}$. There were also an enlarged cervical lymph node in the upper jugular region (IIA group). Computed tomography and magnetic resonance imaging (MRI) revealed a tumour diffusely invading into in to the right side base of tongue. The cervical lymph node (II A) was uniformly enlarged and were impinging on the internal jugular vein and common carotid artery (Fig. 1A). By positron emission tomography, we revealed additional information of primary tumour extension to the supralaryngeal structure - aryepiglottic space and lingual surface of epiglottis (cT3). No more distant metastasis or any other primary tumor was observed on PET-CT. (Fig. 1B).

Under a clinical diagnosis of tongue cancer cT3N1M0, incisional biopsy was performed. The specimen was a tumor sample consisting of moderately differentiated $\mathrm{p} 16$ positive squamous cell cancer cells.

We initially discussed with surgeons about possibility to perform surgery to the patient but did not obtain consent, because of the possibility of functional issues. Therefore, standard radical concurrent chemoradiotherapy with cisplatin had planned.
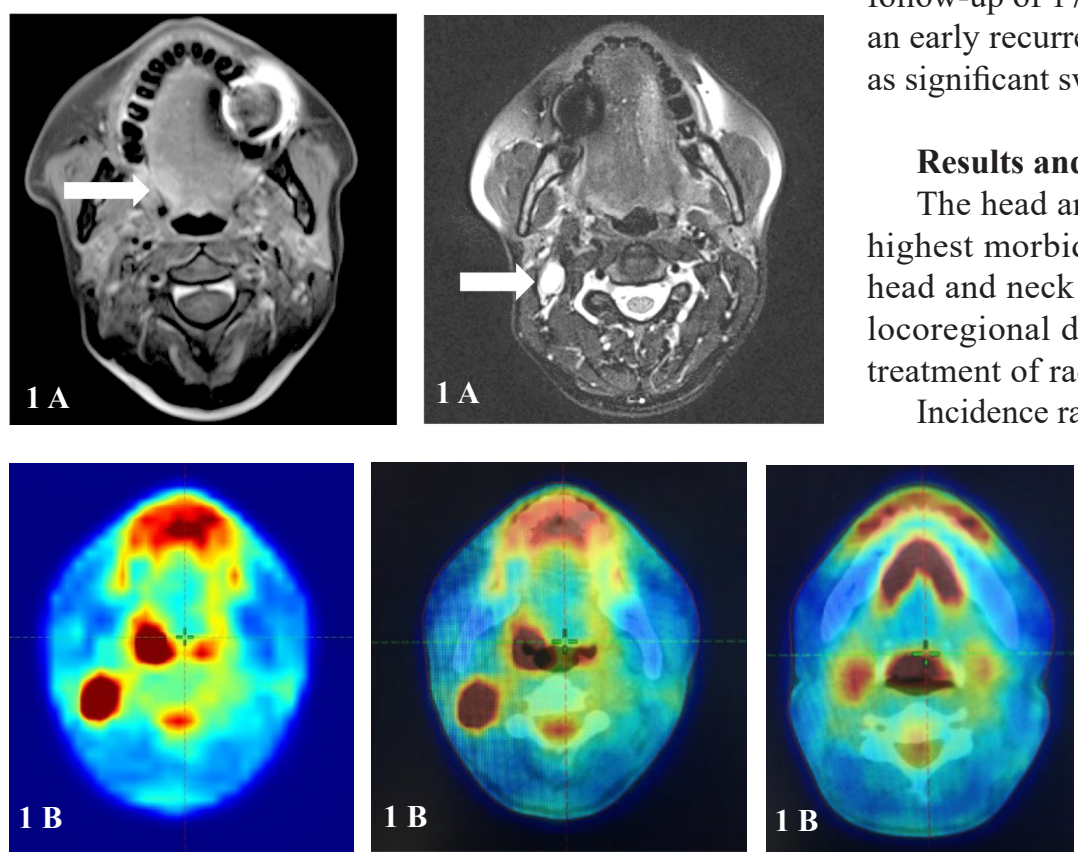

Fig. 1. Magnetic resonance imaging (A) and PET-CT (B). A primary tumour diffusely invading into the right side of base of tongue with extension to lingual surface of epiglottis on the PET CT. The cervical lymph node near the internal jugular vein and common carotid artery was uniformly enlarged.
The total dose of 70 Gy in 35 fractions over 7 weeks with IMRT/VMAT prescribed. The patient received 54 Gy /27 fractions to the lymhnodes followed by a sequential boost of $16 \mathrm{~Gy} / 8$ fractions to gross tumor volume as well as 3 cycles of cisplatin at $100 \mathrm{mg} / \mathrm{m} 2$ during RT.

After two and a halve week after first treatment cycle with cisplatin, the patient developed profound bilateral sensorineural hearing loss (SNHL) (Fig. 2) and chemotherapy was stopped.

The cisplatin-based chemotherapy had changed to alternative agent. The patient continuously underwent concurrently radiation with weekly cetuximab at an initial dose of $400 \mathrm{mg}$ per square meter of body-surface area, followed by $250 \mathrm{mg}$ per square meter weekly without the break of radical radiotherapy course. Despite medical treatment, the patient experienced partial recovery of hearing after treatment of cancer. Moreover, it could be related to the radiotherapy dose to the cochlea, but the mean planned dose (Gy) to these organs at risk was low: to the right cochlea -21,58 Gy and 16,98 Gy to the left side. No severe other adverse events occurred. Only significant leukopenia was observed. Patient had grade 2 acute radiation mucositis and dermatitis after treatment.

The tumor and the metastatic lymph node showed complete response after completing of treatment (Fig.3). During follow-up of 17 months after treatment was no evidence of an early recurrence or any other functional disorders such as significant swallowing problems.

\section{Results and discussion}

The head and neck squamous cell carcinoma have the highest morbidity, accounting for $85 \%$ death among all head and neck cancers [8]. Most patients have advanced locoregional disease at diagnosis and require combined treatment of radiotherapy and systemic therapy [9].

Incidence rates of treatment toxicity such as SNHL after RT and CRT varied considerably, with percentages ranging from $0 \%$ to $43 \%$ and $17 \%$ to $88 \%$, respectively. Factors that influenced the risk of SNHL were radiation dose to the cochlea, follow-up time, age, baseline hearing level, and cisplatin dose. The wide range of SNHL incidence rates makes it impossible to draw any conclusions on the severity of RT and CRT induced ototoxicity [10]. Studies on the incidence and severity of hearing loss in head and neck cancer patients are limited, but those studies suggest that the risk of hearing loss is greater with higher- 
dose regimens of cisplatin [11].

The use of cetuximab as an alternative to high-dose cisplatin and has been increasingly used to treat patients who concern about the toxicity of platinum chemotherapy. The recommendations in Europe differ from those formulated in the NCCN guidelines [5]. There has been no randomized phase III trial reported that compares cetuximab/RT with cisplatin-based CCRT and the only data available are those reported from a phase III trial, comparing cetuximab/RT with RT alone [12], and from a randomized phase II study, comparing cetuximab/RT with cisplatin-based CCRT after cisplatin-based induction chemotherapy $[12,13,14]$.

In addition, a recently published

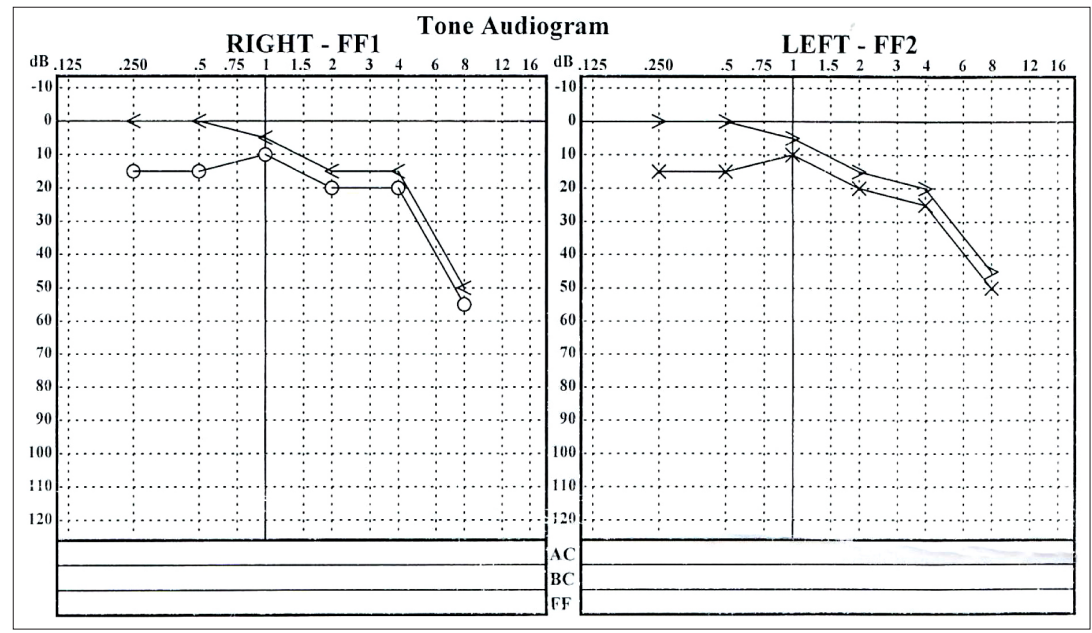

Fig. 2. Tone audiogram of the patient shows profound bilateral sensorineural hearing loss after I cycle of Cisplatin. literature-based meta-analysis on platinum-based CCRT versus cetuximab/RT showed significantly better 2-year results with respect to overall survival, progression-free survival and loco-regional control [14]. The lack of sufficient data addressing these issues confounds decision making. Yet, the choice for the most optimal treatment for an individual patient is a critical issue and therefore a better selection of patients who might need less aggressive therapy versus those who might need more is another important area of research. A comprehensive literature and a meta-analysis of data shows us that the concurrent cetuximab may still be administered to patients who cannot tolerate cisplatin [14,15].

The treatment plan for the patient described in this report was restricted by the toxicity of the CCRT with cisplatin after the first cycle despite young age of patient. The patient tolerance to the bioradiotherapy we decided to follow was acceptable. The tumor and metastatic lymph node showed complete response after completing of radical treatment
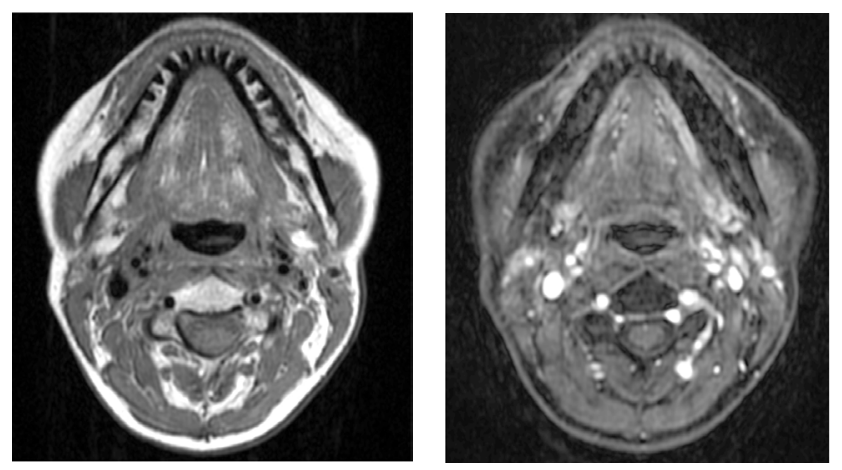

Fig. 3. Magnetic resonance imaging after CCRT shows complete response of primary tumour and metastatic lymphnode
(Fig.3). During follow-up of 17 months after treatment clinically and radiologically was no evidence of an early recurrence or any other functional disorders such as significant swallowing problems. Therefore, we suggest that concurrent bioradiotherapy with cetuximab is one of the option for $p 16$ positive carcinoma of the head and neck cancer replacing cisplatin in case of intolerance.

\section{Conclusions}

Toxicity with only one standard dose of cisplatin can be profound also in young age. This risk should be addressed when counseling patient prior to initiation of treatment. In case of platinum ineligibility, replacing cisplatin with less toxic agent cetuximab may be taken into consideration for p 16 positive squamous cell carcinoma of the oropharynx.

\section{References}

1. Ang KK, Harris J, Wheeler R, Weber R, Rosenthal DI, Nguyen Tân PF, Westra WH, Chung CH, Jordan RC, Lu C, et al. Human papillomavirus and survival of patients with oropha-ryngeal cancer. N Engl J Med 2010; 363:24-35.

https://doi.org/10.1056/NEJMoa0912217

2. Attner P, Du J, Näsman A, Hammarstedt L, Ramqvist T, Lindholm J, Linda Marklund L, Dalianis T, Munck-Wikland E. Human papillomavirus and survival in patients with base of tongue cancer. Int J Cancer 2011;128:2892-2897.

https://doi.org/10.1002/ijc.25625

3. Kofler B, Laban S, Busch CJ, Lörincz B, Knecht R. New treatment strategies for HPV-positive head and neck cancer. Eur Arch Otorhinolaryngol 2014;271:1861-1867.

https://doi.org/10.1007/s00405-013-2603-0

4. Pignon JP, le Maitre A, Maillard E, et al. Meta-analysis of che- 
motherapy in head and neck cancer (MACH-NC): an update on 93 randomised trials and 17,346 patients. Radiother Oncol 2009;92:4-14.

https://doi.org/10.1016/j.radonc.2009.04.014

5. National comprehensive cancer network (NCCN).

https://www.nccn.org/professionals/physician_gls/pdf/headand-neck.pdf

6. Vermorken JB, Mesia R, Rivera F, Remenar E, Kawecki A, Rottey S, Erfan J, Zabolotnyy D, Kienzer HR, Cupissol D, et al. Platinum-based chemotherapy plus cetuximab in head and neck cancer. N Engl J Med 2008;359:1116-1127.

https://doi.org/10.1056/NEJMoa0802656

7. Ahn MJ, Cruz AD, Vermorken JB, Chen JP, Chitapanarux I, Thinh Dang HQ, Guminski A, Kannarunimit D, Lin TY, Tong W, Park KU, Cheung Chan AT. Clinical recommendations for defining platinum unsuitable head and neck cancer patient populations on chemoradiotherapy: a literature review. Oral Oncology 2016;53:10-16.

https://doi.org/10.1016/j.oraloncology.2015.11.019

8. Mehanna H, Paleri V, West CM, et al. Head and neck cancer-Part 1: epidemiology, presentation, and prevention. BMJ 2010;341:c4684.

https://doi.org/10.1136/bmj.c4684

9. Colevas AD, Yom SS, Pfister DG, et al. NCCN guidelines insights: head and neck cancers, version 1.2018. J Natl Compr Canc Netw 2018;16:479-90.

https://doi.org/10.6004/jnccn.2018.0026

10. Theunissen EA, Bosma SC, Zuur CL, Spijker R, van der Baan S, Dreschler WA, de Boer JP, Balm AJ, Rasch CR. Sensorineural hearing loss in patients with head and neck cancer after chemoradiotherapy and radiotherapy: a systematic review of the literature. Head and Neck 2015;37:281-292.

https://doi.org/10.1002/hed.23551

11. Schmitt NC, Page BP. Chemoradiation-induced hearing loss remains a major concern for head and neck cancer patients. Int J Audiol 2018;57:49-54.

https://doi.org/10.1080/14992027.2017.1353710

12. Bonner JA, Harari PM, Giralt J, Azarnia N, Shin DM, Cohen RB, Jones ChU, Sur R, Raben D, Jassem J, Ove R, Kies MS, Baselga J, et al. Radiotherapy plus cetuximab for squamous-cell carcinoma of the head and neck. N Engl J Med 2006;354:567-78.

https://doi.org/10.1056/NEJMoa053422

13. Lefebvre J, Pointreau Y, Rolland F, et al. Sequential chemoradiotherapy (SCRT) for larynx preservation. J Clin Oncol 2012;30:360s (suppl 15; abstr 5501).

https://doi.org/10.1200/jco.2011.29.15_suppl.5501
14. Tang WH, Sun W, Long GX. Concurrent cisplatin or cetuximab with radiotherapy in patients with locally advanced head and neck squamous cell carcinoma. A meta-analysis. Medicine (Baltimore) 2020;99(36).

https://doi.org/10.1097/MD.0000000000021785

15. Amini A, Eguchi M, Jones BL, et al. Outcomes between concurrent cisplatin versus cetuximab in locally advanced oropharyngeal carcinoma: a seer-medicare analysis. Int J Radiat Oncol 2018;100:1335.

https://doi.org/10.1016/j.ijrobp.2017.12.077

\section{SUTAPTINIS BURNARYKLĖS VĖŽIO BIOSPINDULINIS GYDYMAS, JAUNAI PACIENTEI PO PIRMO CISPLATINOS CIKLO NUSTAČIUS ABIPUSİ NEUROSENSORINI KLAUSOS NERVO PAŽEIDIMĄ}

\section{A. Plieskienė, A. Česas}

Raktažodžiai: sutaptinis chemospindulinis gydymas, cisplatina, cetuksimabas, žmogaus papilomos virusas, burnaryklès vėžys.

Santrauka

Radikalus sutaptinis chemospindulinis gydymas dažnai skiriamas vietiškai išplitusio galvos-kaklo véžio gydymui, kai radikali operacija neįmanoma arba siekiama geresnès funkcijos po gydymo. Plokščialąstelinès p16 teigiamos karcinomos radikalaus chemospindulinio gydymo rezultatai yra patys geriausi, tačiau klinikinejje praktikoje susiduriame su cisplatinos toksiškumu, kuris pasireiškia net ir jauname amžiuje.

Straipsnyje pristatomas klinikinis atvejis, kai po pirmojo chemoterapijos ciklo, skiriant sutaptinị vietiškai išplitusio burnaryklès vėžio chemospindulinị gydymą, pasireiškè abipusis neurosensorinis klausos nervų pažeidimas, lèmęs pacientès apkurtimą. Nutraukus cisplatinos skyrimą, radikali radioterapija toliau buvo skiriama kartu su cetuksimabu. Aktyviai stebint pacientę po biospindulinio gydymo, per 17 mèn. nebuvo nustatyta vietinio burnaryklès vėžio atkryčio ir metastazių. Manome, kad gydant vietiškai išplitusius galvos kaklo piktybinius navikus radikalia radioterapija su cisplatina, nustačius sunkų šalutinị poveikị ir netoleruojant chemoterapijos, cisplatiną galima pakeisti bioradioterapija su cetuksimabu.

Adresas susirašinėti: plieskiene@kul.lt

Gauta 2020-11-26 